\title{
Discovery of and Recovery from Failure in a Costal Marine USN Service
}

\author{
Hee-Taek Ceong ${ }^{*}$, Hae-Jin Kim, and Jeong-Seon Park, Member, KIICE \\ Department of Digital Convergence, Chonnam National University, Yeosu 550-749, Korea
}

\begin{abstract}
In a marine ubiquitous sensor network (USN) system using expensive sensors in the harsh ocean environment, it is very important to discover failures and devise recovery techniques to deal with such failures. Therefore, in order to perform failure modeling, this study analyzes the USN-based real-time water quality monitoring service of the Gaduri Aqua Farms at Songdo Island of Yeosu, South Korea and devises methods of discovery and recovery of failure by classifying the types of failure into system element failure, communication failure, and data failure. In particular, to solve problems from the perspective of data, this study defines data integrity and data consistency for use in identifying data failure. This study, by identifying the exact type of failure through analysis of the cause of failure, proposes criteria for performing relevant recovery. In addition, the experiments have been made to suggest the duration as to how long the data should be stored in the gateway when such a data failure occurs.
\end{abstract}

Index Terms: Wireless sensor network, Ubiquitous sensor network, USN service, Aqua farm, Failure recovery, Marine water quality monitoring

\section{INTRODUCTION}

Ubiquitous sensor network (USN) technology allows a user to freely access the network anytime, anywhere and is one of the hot technologies studied around the world based on the "ubiquitous" paradigm for the IT environment [1]. A ubiquitous environment is based on the broadband wire infrastructure, and is implemented with the convergence with wireless techniques [2]. In South Korea, the government has played a leading role in performing various USN-applied projects since 2005 in the areas of construction, health, national defense, and logistics as well as environmental areas such as weather/marine observation, disaster observation, water resource management and agricultural product management [3, 4]. And some visible accomplishments of such projects have been appearing recently [5-8].

The USN system is built in a wireless sensor network environment, consisting of sensors supplied with limited electric power inaccessible under certain restricted poor conditions, thereby enabling it to manage surrounding environmental information such as temperature, humidity, pollution, and crack information [2, 4]. It is necessary to design a USN system taking into account failure permission, failure discovery, recovery techniques, and so on, so that failure of certain sensors does not prevent the automatic collection of data and does not have an impact on the whole system [9-15]. For USN systems using expensive sensors in

Received 16 November 2011, Revised 15 December 2011, Accepted 20 December 2011

*Corresponding Author E-mail: htceong@jnu.ac.kr 
harsh environments such as marine systems underwater or in the ocean, it is especially important to discover failure and devise recovery techniques to deal with such failure [16, $17]$.

Thus, this study, in order to modeling a failure of a coastal marine USN environment, analyzes the USN-based real-time water quality monitoring service built to manage the environment of Gaduri Aqua Farms at Songdo Island of Yeosu, South Korea [7], classifies failures into system element failures, communication failures, and data failures, and proposes recovery techniques. In addition, in order to identify data failures, data consistency and data integrity are defined, and the duration of stored data at the gateway stage are also suggested through implementing experiments using the data on observed marine water quality.

This paper is composed as follows. Section II covers the overview of USNs in general by introducing wireless sensor networks (WSNs) and USNs, the structure and technology of USNs, and some case studies for detection of USN failure and recovery techniques. Section III describes the analysis of marine USN systems on the characteristics of the marine environment, presents a case study of a marine USN application and a U-aqua farm environment management system used for modeling the failures of this study, which supplies real-time water quality information to Gaduri Aqua Farms at Songdo Island of Yeosu. Section IV, describing the identification of failures and recovery techniques, classifies failure into three types, defines data consistency and data integrity used in the identification of data failure, and presents experiments on consistency and integrity at the time of identifying data failures. Each recovery technique is drawn by the defined failure types. Lastly, conclusions and future research directions are stated in section $\mathrm{V}$.

\section{THE USN IN GENERAL}

\section{A. WSN and USN}

A sensor network consists of sensors that form a network, and is also known as a WSN or USN. Studies outside Korea on sensor networks generally use the term WSN instead of USN. The Ministry of Information and Communication of Korea uses the term USN in the IT839 strategy as a network that recognizes and manages the information of various objects by linking radio frequency identification (RFID) tags and $\mathrm{u}$-sensors to broadband convergence network $(\mathrm{BcN})$, thereby defining the basic infrastructure to realize an ubiquitous society by expanding existing humanoriented information to objects $[4,5]$. Therefore, USN can be viewed as a broader concept that includes the concept of WSN. WSN is defined as realization of wireless-based sensor networks by combining wireless radio frequency (RF) technology such as Zigbee, Bluetooth, and Wi-Fi, and network technology such as ad-hoc and mesh networking to existing wire-based sensor nodes $[1,4]$.

The major functions of sensor network are noted in Table 1. This system is composed of sensor nodes equipped with sensors having various functions and transmits sensed information to synch nodes by a network using single-hop or multi-hop. The gateway, which receives data from sensor nodes and synch nodes, then transmits the sensed data to the server through an IP-based network (LAN, WLAN, CDMA, WiBro, satellite, etc.) in order to use various contents or services.

Table 1. Function of sensor network

\begin{tabular}{ll}
\hline Types of node & \multicolumn{1}{c}{ Function } \\
\hline Sensor node & $\begin{array}{l}\text { Node which transmits sensed data to synch node } \\
\text { and gateway node }\end{array}$ \\
Synch node & $\begin{array}{l}\text { Node which receives data transmitted by sensor } \\
\text { node, and integrates it or transmits it to gateway } \\
\text { node }\end{array}$ \\
Gateway node & $\begin{array}{l}\text { Node which transmits data transmitted from } \\
\text { sensor node and synch node to IP-based network } \\
\text { services }\end{array}$ \\
\hline
\end{tabular}

\section{B. Structure and Technology USN}

Fig. 1 shows the structure of USN, which senses information on objects and environment from RFID tags and sensors, stores and processes such information, and transfers it through the internet [5].

Sensor nodes are the basic elements comprising a USN and a network desired by users can be built of them using wire/wireless communication technology [1]; that is, various wire/wireless network technologies such as Zigbee, Bluetooth, ultra-wideband (UWB), Wi-Fi, serial, and ethernet can be used. A sensor node is a micro computing system that perceives, analyzes, and transmits information sensed in the environment and physical world and consists mainly of a microcontroller unit (MCU), wireless communications unit, sensor unit, and electric power unit. A synch node is a system that collects data sensed by the sensor nodes, links to event-type data outside of the sensor network, manages the relevant sensor network, and is usually a system with a bigger hardware and software capacity than that of the sensor nodes [1]. Gateway, a system linking an IP-based network (LAN, WLAN, CDMA, WiBro, Satellite, etc.) and sensor network, is located between the synch nodes and existing service network. If necessary, the synch nodes can be installed within a gateway [1]. 


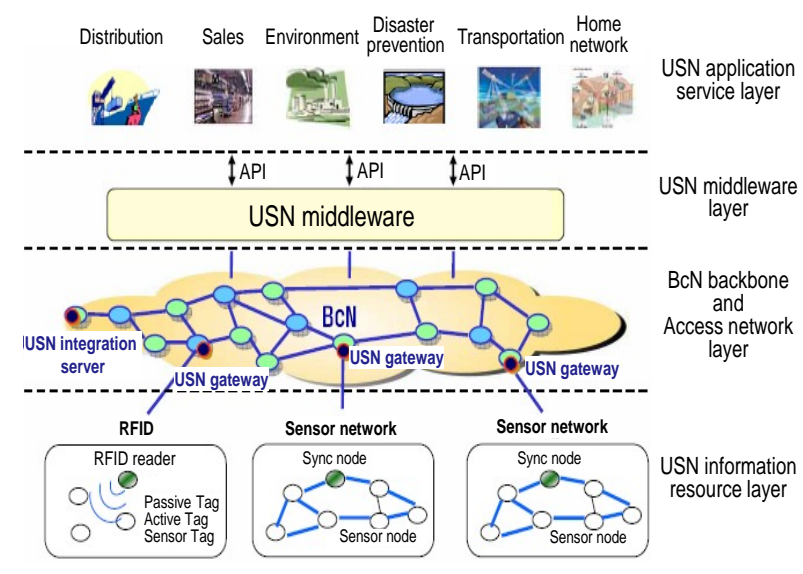

Fig. 1. Structure of ubiquitous sensor network (USN) [5]. API: application program interface, BcN: broadband convergence network, RFID: radio frequency identification.

USN technology includes wireless communication technology, server-level USN middleware technology linking USN to a management and information system, sensor node middleware technology, the recentlyemphasized USN information protection technology, and USN application technology realized by using all the technologies $[1,2,18]$.

\section{Case Studies of USN Failure Detection and Techniques for Recovery}

Failure of the sensor nodes and sensors, which are the core elements of a USN, may cause plenty of problems for maintaining the quality of services within the network, and in the worst case may even bring entire network system failure [9]. The failures that can occur at the sensors and sensor nodes may be classified into hard failures including electric power depletion and hardware part failure, and soft failures including calibration errors and random noise errors of various sensors installed at sensor nodes. There are cases in which a failure detection algorithm, the type that combines the consensus algorithm and localized faulty sensor detection (LFSD) algorithm, which can detect both the hard failure and soft failure simultaneously [9].

There are also studies on techniques for recovering sensors in the failed gateway, rather than shutting down the system or re-clustering the whole system, when a failure occurs in the multi-tier structure of a wireless sensor network. This recovery technique is to re-associate the sensors managed by the failed gateway to other clusters based on the backup information created during clustering by checking the status of the gateway periodically $[10,11]$. There are also case studies permitting through proposing a heterogeneous backup schema that replaces a type of sensor with another type of sensor, based on the fact that a sensor node has a high rate of sensing failure for a sensor network permitting low overhead failure [12].

Sensor nodes with limited communication bandwidth and electric power must perform cooperation, which is an effective way to maintain communication and electric power and is resistant to failure. From the perspectives of communication cost, precision, accuracy, and number of recoverable failure sensors in the sensor network, value fusion and decision fusion have each been suggested as an effective cooperation-type target detection algorithm. The value fusion algorithm has better performance when no sensor node failure occurs, while the decision fusion based algorithm is preferred for lower communication overhead when a failure occurs. To improve detection performance, a study on the optimum arrangement of sensors in an area of interest is also necessary [13].

However, the above mentioned studies lack consideration for the harsh marine environment where failure frequently occurs due to the environmental changes and its difficulty for recovering the failure. Also, the problems of data failure, which is the main focus of this study, are not stated in that report.

\section{ANALYSIS OF A MARINE USN SYSTEM}

\section{A. Characteristics of a Marine USN}

A marine USN is a system that recognizes marine resources or their environment by installing sensor nodes fixed either on the ocean floor or underwater, builds and manages real-time information through network, and allows a user to control and manage it on the ground $[16,17]$.

A marine USN is a kind of wireless sensor network that combines undersea wireless communication technology and sensing technology, and links undersea wireless communication technology to ground communication. It is difficult to directly apply land-based sensor network technology to marine USNs due to the characteristics of their environment. In a marine USN, compared with the general land-based USNs, sensors and sensor nodes are more expensive and more difficult to deploy, so it is necessary to design a network with sufficient ruggedness and reliability.

Marine sensors currently in commercial use are especially big, heavy, and mostly expensive, and their power consumption is generally not small. Marine sensor units rapidly corrode, with undersea life and salinity often shortening their lifespan [16]. Since a marine USN has to efficiently manage an expensive marine sensor system placed in a harsh environment such as under the sea, it is necessary to develop a technology to discover and recover from failure rapidly.

A marine USN, for the purpose of efficient data 
transmission under limited environmental conditions, should have strengthened performance including that of local data storage, and it also becomes necessary to develop a node management function that properly adjusts the sensing and transmission interval [16].

\section{B. A Case Study of a Marine USN}

In order to develop business models, USN application services have been performed since 2005 under an initiative of the government of Korea by applying USN technology to various objects and environments. Table 2 shows Korean field tests and pilot projects in which USN technology is applied to marine areas [4-8].

Table 2. Marine USN field tests and pilot projects

\begin{tabular}{|c|c|c|}
\hline $\begin{array}{l}\text { Project name } \\
\quad(\mathrm{yr})\end{array}$ & Organization & Contents \\
\hline $\begin{array}{l}\text { USN-based } \\
\text { Jeju coastal } \\
\text { marine } \\
\text { environment } \\
\text { information } \\
\text { collection } \\
\text { system (2005) }\end{array}$ & $\begin{array}{l}\text { Sisnet Co, Jeju } \\
\text { Knowledge } \\
\text { Promotion Agency }\end{array}$ & $\begin{array}{l}\text { Collects processes and analyzes } \\
\text { Jeju's coastal marine environ- } \\
\text { mental data in a real-time } \\
\text { manner. Monitors marine } \\
\text { ecology changes according to } \\
\text { the weather changes by } \\
\text { installing sensors for dissolved } \\
\text { oxygen, temperature, and } \mathrm{pH} \text {. }\end{array}$ \\
\hline $\begin{array}{l}\text { USN-based } \\
\text { weather/marine } \\
\text { observation } \\
\text { system (2006) }\end{array}$ & $\begin{array}{l}\text { KT Future } \\
\text { Technology } \\
\text { Research Institute, } \\
\text { Korea } \\
\text { Meteorological } \\
\text { Administration, } \\
\text { Korea Hydrographic } \\
\text { Oceanographic } \\
\text { Administration }\end{array}$ & $\begin{array}{l}\text { Collects real-time weather } \\
\text { information such as } \\
\text { temperature, atmospheric } \\
\text { pressure, moisture, wind } \\
\text { direction, and rainfall in the } \\
\text { Seongsan area of Jeju. } \\
\text { Monitors weather information } \\
\text { by various weather sensors and } \\
\text { sensor nodes. }\end{array}$ \\
\hline $\begin{array}{l}\text { U-Ulleungdo } \\
\text { and Dokdo } \\
\text { disaster early } \\
\text { forecasting } \\
\text { system (2007) }\end{array}$ & $\begin{array}{l}\text { Iljin Networks } \\
\text { Consortium, } \\
\text { Gyeongsangbuk-do }\end{array}$ & $\begin{array}{l}\text { A real-time data management } \\
\text { system by USN of installed } \\
\text { sensors for water level, flow } \\
\text { speed, wave height, rainfall, and } \\
\text { temperature in Ulleungdo and } \\
\text { Dokdo docking facilities. }\end{array}$ \\
\hline $\begin{array}{l}\text { ALL-IP based } \\
\text { USN } \\
\text { observation } \\
\text { system (2007) }\end{array}$ & $\begin{array}{l}\text { KT Future } \\
\text { Technology Research } \\
\text { Institute }\end{array}$ & $\begin{array}{l}\text { Collects weather information } \\
\text { (temperature, moisture, wind } \\
\text { speed, rainfall, etc.) and marine } \\
\text { information (water temperature, } \\
\text { salinity, atmospheric pressure, } \\
\text { temperature, etc.) in real-time } \\
\text { and provides weather and } \\
\text { marine information to weather } \\
\text { forecasting and fishing boats. }\end{array}$ \\
\hline $\begin{array}{l}\text { Suncheon Bay } \\
\text { USN marine } \\
\text { cluster and } \\
\text { convergence } \\
\text { service system } \\
(2010)\end{array}$ & $\begin{array}{l}\text { SK C\&C, Korea } \\
\text { Hydrographic } \\
\text { Oceanographic } \\
\text { Administration }\end{array}$ & $\begin{array}{l}\text { Collects marine weather } \\
\text { information such as water } \\
\text { temperature, salinity, and water } \\
\text { quality of Suncheon Bay and } \\
\text { provides in real-time, and } \\
\text { transmits a panoramic CCTV } \\
\text { view of Suncheon Bay to PDP, } \\
\text { etc. based on wire/wireless } \\
\text { communication technology and } \\
\text { CDMA, and shows } \\
\text { environmental information on } \\
\text { LED screens. }\end{array}$ \\
\hline
\end{tabular}

In the USN-based Jeju costal marine environment information system, buoys mounted with Zigbee sensor nodes are installed and marine environment information is collected through USN. This USN based weather and ocean observation system has been applied as a pilot program of wireless mesh network technology in islands and ocean areas where it is difficult to expand existing network infrastructure. In the U-Ulleungdo and Dokdo disaster early forecasting system, data measured by sensors can be transmitted to, stored in, and managed by servers in realtime through a high speed internet network and CDMA. In the ALL-IP-based USN observation system, an IP-USN and wireless mesh network were introduced as a pilot program to build a USN-based observation network. Also, data is transferred to the server through sensors, gateways, a wireless mesh network, and an internet link. In the Suncheon Bay USN marine cluster and convergence service, an $800 \mathrm{MHz}$-bandwidth CDMA wireless network and wire/wireless private network were built so that various observation devices installed in Suncheon Bay can collect data and provide information in real time.

The feasibility of the pilot projects in Table 2 was verified by applying them to public sectors such as weather/marine sectors with high utilization of and demand for a USN and the projects contributed to the popularization and promotion of the USN. These service models were proposed a way that involved installing a sensor node and gateway as a link between the sensor network and network infrastructure. Also, it was proven that a wireless mesh network could be used as the infrastructure for a USN installation area in which it was difficult to build wire networks [5].

\section{System Analysis for Failure Modeling}

For modeling of failure-tolerant functions and failurerecovery techniques of marine USNs, we investigated and analyzed a U-aqua farm environmental management system, which is a marine water quality environmental monitoring system for Gaduri Aqua Farms at Songdo Island of Yeosu [7]. Fig. 2 shows a diagram of the U-aqua farm environment management system.

Three sets of sensors and sensor logger systems have been built in the neighboring area and inner area of the Gaduri Aqua Farms. A sensor logger system collects information sensed by the sensors and stores it in a self local storage to prevent any data loss. The data in the sensor logger is transmitted to the integrated operation server through the wireless mesh network, and now, the services providing water quality environment information become available over the website. The wireless communicationtype sensor logger system consists of water quality sensors measuring the water quality environment, sensor nodes 
managing the data received from the sensors and performing a defined data protocol transformation, and a gateway linking sensor node to the communications network.

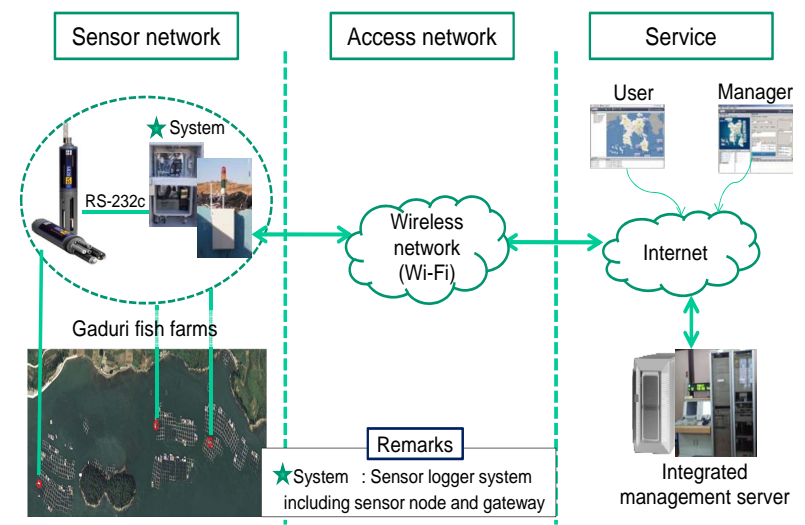

Fig. 2. Configuration of U-aqua farm environmental management system.

Fig. 3 shows the interior and exterior of the sensor logger system. As a marine water quality sensor is expensive, and it is costly to install multiple sensors, we provided storage space for the sensor to store sensed data for a certain period of time.
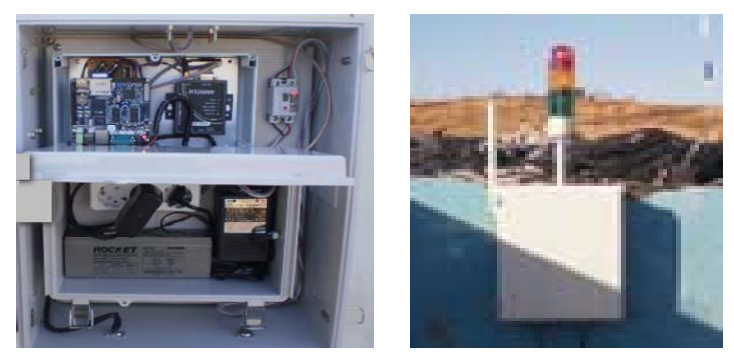

Fig. 3. Interior and exterior of sensor logger system.

\section{FAILURE IDENTIFICATION AND RECOVERY TECHNIQUES}

\section{A. Classification of Failures}

In the test system for failure modeling, data is transmitted from the sensor via a sensor logger containing a sensor node and gateway, to the access point (AP) and database server. As marine water quality environmental data should be transmitted with accuracy, the transmission should recover quickly from errors when failure occurs. In this study, the types of failure are classified into system element failure, communication failure, and data failure.

\section{1) System Element Failure}

System element failure is caused by hardware or software failure. System failure is classified, based on the types of devices, into that of a sensor, that of a sensor logger containing a sensor node and gateway, and that of a database server, as shown in Table 3 . The remark column in the table notes the types of failure on the existing distributed system that were studied. Sensor failure occurs where a sensor physically fails due to conditions such as salinity or is lost by a sea current, typhoon, etc., and can be measured by whether there is a response to the gateway's periodic request for data. Sensor logger failure is a failure of the system to transmit certain data to the server and can be discovered by using a timeout from the server to the gateway. Lastly, failure of the database server can be discovered by failure to service the stored data for a long period of time.

Table 3. System element failure

\begin{tabular}{|c|c|c|c|}
\hline $\begin{array}{c}\text { Failure } \\
\text { specification }\end{array}$ & Reason & Detection method & Remarks \\
\hline $\begin{array}{l}\text { Water quality } \\
\text { measuring } \\
\text { sensor }\end{array}$ & $\begin{array}{l}\text { Physical failure or } \\
\text { loss of sensor }\end{array}$ & $\begin{array}{l}\text { Discovered when } \\
\text { there is no response } \\
\text { to request from } \\
\text { gateway to sensor } \\
\text { for data at certain } \\
\text { intervals }\end{array}$ & $\begin{array}{l}\text { Time } \\
\text { failure }\end{array}$ \\
\hline Gateway & $\begin{array}{l}\text { Failure of the } \\
\text { gateway, which } \\
\text { holds data } \\
\text { transferred from } \\
\text { sensor }\end{array}$ & $\begin{array}{l}\text { Discovered when } \\
\text { relevant gateway } \\
\text { fails to transmit } \\
\text { data to database } \\
\text { server }\end{array}$ & $\begin{array}{l}\text { Crash-stop } \\
\text { failure } \\
\text { Time } \\
\text { failure }\end{array}$ \\
\hline $\begin{array}{l}\text { Database } \\
\text { server }\end{array}$ & $\begin{array}{l}\text { Failure of the } \\
\text { server, which stores } \\
\text { transferred data }\end{array}$ & $\begin{array}{l}\text { Discovered when } \\
\text { user interface } \\
\text { cannot access } \\
\text { current status }\end{array}$ & $\begin{array}{l}\text { Time } \\
\text { failure }\end{array}$ \\
\hline
\end{tabular}

\section{2) Communication Failure}

Communication failure occurs in the process of data transmission using a wire/wireless communication network. The categories of communication failures that we noted include the following: the failure in updated recent data is not transmitted due to a cable failure in the wire communication between the water quality measurement sensor and sensor node, the failure in which the data maintained at the gateway is not transmitted to the server in the communication between the gateway and AP, and the failure that occurs due to a propagation collision caused by interference. This article focuses on the communication failures shown in Table 4.

In case of wire communication (RS-232C) between a sensor and sensor node, a failure can occur in which data is not transmitted to the gateway, even though the sensor measures the data correctly. The gateway is not easily accessible as they are installed in a harsh environment; therefore, a timeout method is established, and a failure is identified when no response is made at the periodic data 
request to the sensor from the gateway.

Table 4. Communication failures

\begin{tabular}{|c|c|c|c|}
\hline $\begin{array}{c}\text { Failure } \\
\text { specification }\end{array}$ & Reason & $\begin{array}{l}\text { Detection } \\
\text { method }\end{array}$ & Remarks \\
\hline $\begin{array}{l}\text { Wire } \\
\text { communication } \\
\text { between water } \\
\text { quality } \\
\text { measuring } \\
\text { sensor and } \\
\text { gateway } \\
\text { (RS-232C) }\end{array}$ & $\begin{array}{l}\text { Failure in which } \\
\text { a sensor } \\
\text { performs } \\
\text { measurement } \\
\text { accurately but } \\
\text { fails to transfer } \\
\text { it to the gateway }\end{array}$ & $\begin{array}{l}\text { Discovered } \\
\text { when there is no } \\
\text { response for the } \\
\text { periodic data } \\
\text { request by the } \\
\text { gateway }\end{array}$ & Time failure \\
\hline \multirow[t]{2}{*}{$\begin{array}{l}\text { Wireless } \\
\text { communication } \\
\text { between } \\
\text { gateway and } \\
\text { database } \\
\text { server } \\
(\mathrm{Wi}-\mathrm{Fi})\end{array}$} & $\begin{array}{l}\text { Failure in which } \\
\text { data held in the } \\
\text { gateway is not } \\
\text { transferred to } \\
\text { the database } \\
\text { server }\end{array}$ & $\begin{array}{l}\text { Discovered } \\
\text { when data is not } \\
\text { transmitted to } \\
\text { the database } \\
\text { server from } \\
\text { relevant gateway }\end{array}$ & Time failure \\
\hline & $\begin{array}{l}\text { Limitation on } \\
\text { communication } \\
\text { distance }\end{array}$ & $\begin{array}{l}\text { Failure is } \\
\text { identified by the } \\
\text { monitoring } \\
\text { program due to } \\
\text { the } \\
\text { communication } \\
\text { failure with } \\
\text { broken the time } \\
\text { information of } \\
\text { data unless } \\
\text { communication } \\
\text { distance is } \\
\text { secured }\end{array}$ & $\begin{array}{l}\text { Set up the } \\
\text { directional } \\
\text { antennas at the } \\
\text { two gateways } \\
\text { where the } \\
\text { communication } \\
\text { distance is not } \\
\text { secured }\end{array}$ \\
\hline
\end{tabular}

For the wireless communication (Wi-Fi) between the gateway and database server, first, failure occurs when the data maintained at the gateway is not transmitted to the server, and is identified when no data transmission is made from the database server to the corresponding gateway. By installing a timeout, a failure is identified when no response is made at the periodic data request to the sensor from the gateway. Secondly, unless the communication distance is secured, a communication failure occurs and the date or year of the data is transmitted broken and this can be checked by a monitoring program.

For the U-aqua farm environment management system, two out of three gateways are currently placed at positions in excess of the designated distance from the database server, so a directional antenna was installed at the database server. However, the problem of limited distance is not solved in uncertain situations (due to rain, wind, etc.) so sometimes the date or year of the data is still transmitted broken.

\section{3) Data Failure}

For the U-aqua farm environment management system, data failure occurs in the course of data transmission, and accurate data is not transmitted. In other words, the data generated in the unit element and received data are either inconsistent, or against integrity, which is described in Table 5.

Table 5. Data failure

\begin{tabular}{|c|c|c|c|}
\hline $\begin{array}{c}\text { Failure } \\
\text { specification }\end{array}$ & Reason & $\begin{array}{l}\text { Detection } \\
\text { method }\end{array}$ & Remarks \\
\hline $\begin{array}{l}\text { Date (water } \\
\text { quality } \\
\text { measuring } \\
\text { sensor) }\end{array}$ & $\begin{array}{l}\text { Failure in which one or } \\
\text { more water quality } \\
\text { measuring sensors create } \\
\text { data exceeding the } \\
\text { sensor's measurement } \\
\text { capacity or certain other } \\
\text { range }\end{array}$ & $\begin{array}{l}\text { Discovered } \\
\text { through } \\
\text { verification of } \\
\text { data transferred } \\
\text { from sensors to } \\
\text { gateway }\end{array}$ & \\
\hline $\begin{array}{l}\text { Date (water } \\
\text { quality } \\
\text { measuring } \\
\text { sensor) } \neq \text { Data } \\
\text { (gateway) }\end{array}$ & $\begin{array}{l}\text { Failure in which the data } \\
\text { measured by water } \\
\text { quality sensor differs } \\
\text { from the data held by } \\
\text { gateway }\end{array}$ & & $\begin{array}{l}\text { Response } \\
\text { value } \\
\text { failure }\end{array}$ \\
\hline $\begin{array}{l}\text { Data } \\
\text { (gateway) }\end{array}$ & $\begin{array}{l}\text { Failure in which data } \\
\text { maintained in one or } \\
\text { more gateways exceeds } \\
\text { certain range }\end{array}$ & $\begin{array}{l}\text { Discovered } \\
\text { through } \\
\text { verification of } \\
\text { data transferred } \\
\text { from each }\end{array}$ & \\
\hline $\begin{array}{l}\text { Data } \\
\text { (gateway) } \neq \\
\text { Data (database } \\
\text { server) }\end{array}$ & $\begin{array}{l}\text { Failure in which the data } \\
\text { of gateway differs from } \\
\text { the data of database } \\
\text { server }\end{array}$ & $\begin{array}{l}\text { gateway to the } \\
\text { database server }\end{array}$ & $\begin{array}{l}\text { Response } \\
\text { value } \\
\text { failure }\end{array}$ \\
\hline
\end{tabular}

In particular, for the marine water quality data, data failure can be identified whether or not to satisfy consistency and integrity as defined below.

\section{Definition 1. Consistency of marine water quality data}

The data measured from $\mathrm{m}$ number of marine water quality sensors is defined as $D_{i}=\left\{s_{1}, s_{2}, \ldots, s_{m}\right\}$, and if the data $s_{n+1}$, measured at time $\mathrm{n}+1$ (i.e. most recently measured), meets the following equation (1), then we say $s_{n+1}$ maintains consistency.

$$
s_{n+1}^{*}+\alpha \leq s_{n+1} \leq s_{n+1}^{*}+\beta
$$

where, $s_{n+1}^{*}$ is the estimated data at time $\mathrm{n}+1$ from the $\mathrm{r}$ holding recent data, the $\alpha$ and $\beta$ are the acceptance constants designated by the user, and $r$ is the number of recent data to be used as well as being a constant designated by the user.

In the above definition 1 , the constants proposed $\alpha, \beta$, and $\mathrm{r}$ can be created by statistical analysis reflecting seasonal elements of measured water quality data, etc.

\section{Definition 2. Integrity of marine water quality data}

When the data measured from $m$ number of marine water 
quality sensors is defined as $D_{i}=\left\{s_{1}, s_{2}, \ldots, s_{m}\right\}$, we say $s_{i}$ meets integrity if a random datum $s_{i}$ meets the following formula,

$$
L B\left(s_{i}\right) \leq s_{i} \leq U B\left(s_{i}\right)
$$

where $L B\left(s_{i}\right)$ and $U B\left(s_{i}\right)$ mean the lower and upper limit for each corresponding datum, respectively.

In definition 2, the constants $L B\left(s_{i}\right)$ and $U B\left(s_{i}\right)$ can be designated through statistical analysis reflecting seasonal factors or within the range that the sensor can measure.

From the previous two definitions, data failure can be identified on the basis of whether the measured marine water quality data meets conditions for consistency and integrity. Meanwhile, in order to identify such failure, it is necessary to hold data for a certain period of time. The length of much time necessary can be decided by $r$ value used in the definition of consistency. The result of the experiment for deciding on the $r$ value is shown in the following subsection.

\section{B. Experiment to Verify Data Failure}

The data used in the experiment is the marine data of the Goheung Wave Level Observatory Station provided by the Korea Hydrographic and Oceanographic Administration [6]. The station collected environmental data, the daily mean values of hourly observed data including temperature, water temperature and salinity from January 1, 2008 to July 31, 2010. Fig. 4 shows the data collected for water temperature $\left({ }^{\circ} \mathrm{C}\right)$ and salinity (\%o) used as our experiment data.

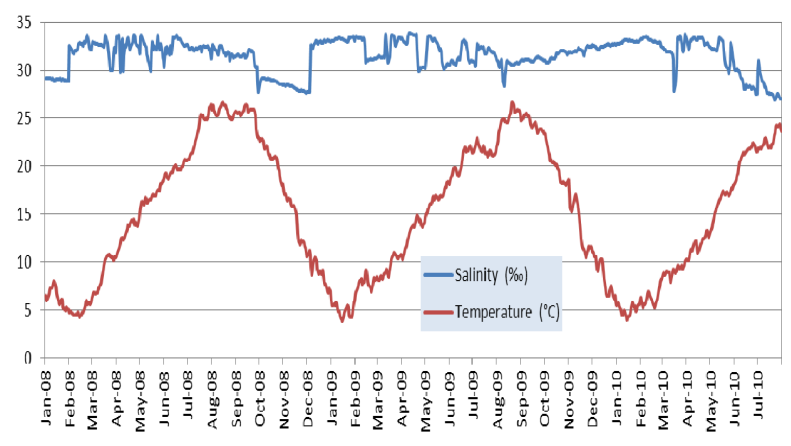

Fig. 4. Collected data of water temperature and salinity from January 1, 2008 to July $31,2010$.

In order to designate the upper and lower limits of integrity, we refer the maximum and minimum value of water temperature and salinity as shown in Fig. 5.

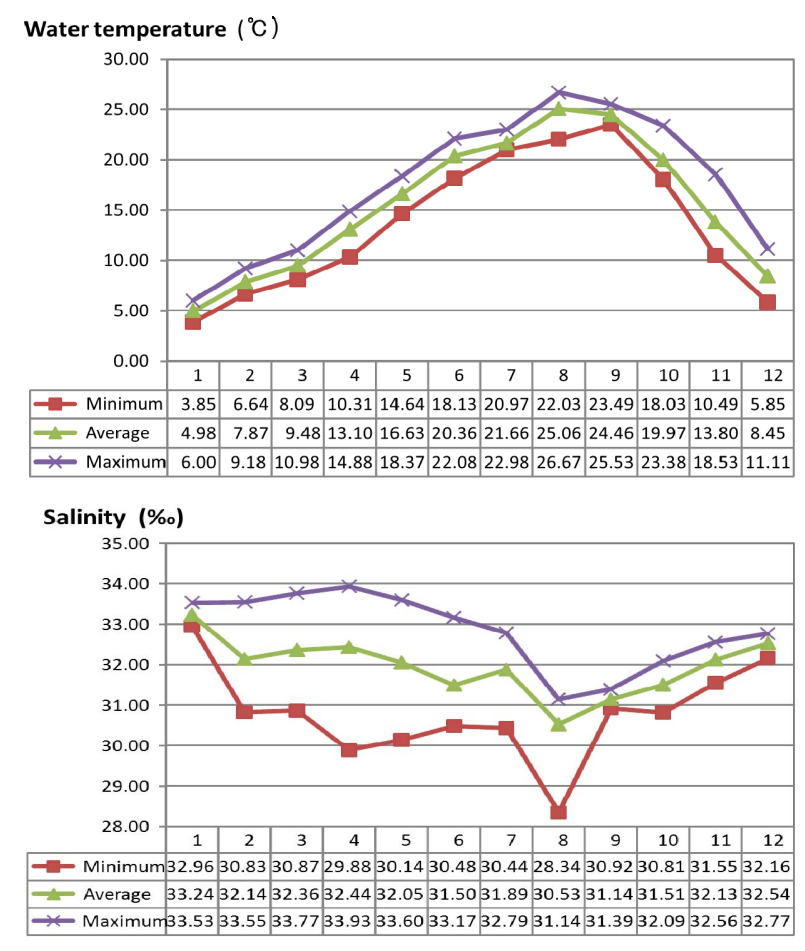

Fig. 5. Monthly trends for water temperature and salinity in 2009.

Next, the consistency verification experiment with regard to water temperature was performed. First, in order to decide on the $r$ value, the number of recent data points to hold; experiments on a yearly, quarterly, and seasonal basis have been carried out. To estimate the next value, $s_{n+1}^{*}$ from the $r$ holding recent data, we used the following polynomial curve fitting equations according to the $r$,

$$
\begin{aligned}
& r=1: \quad s_{n+1}^{*}=s_{n} \\
& r=2: \quad s_{n+1}^{*}=p_{1} x+p_{2} \\
& r \geq 3: \quad s_{n+1}^{*}=p_{1} x^{2}+p_{2} x+p_{3}
\end{aligned}
$$

where the parameters $p_{1}, \ldots, p_{3}$ are determined to minimize the following mean squared error (MSE) between $r$ observation data and estimated data.

$$
M S E=\frac{\sum_{i=n-r-1}^{n}\left(s_{i}-s_{i}^{*}\right)^{2}}{r}
$$

As a result, most graphs become forms of values increasing to the degree that $r$ 's are increasing; however, decreasing periods have been noted in the seasonal experiments between March 2009 and Feb. 2010.

From Fig. 6, we can confirm that the value is decreasing when $r=3$, and that the temperature is increasing in the 
spring and summer, while the temperature is decreasing in the fall and winter.

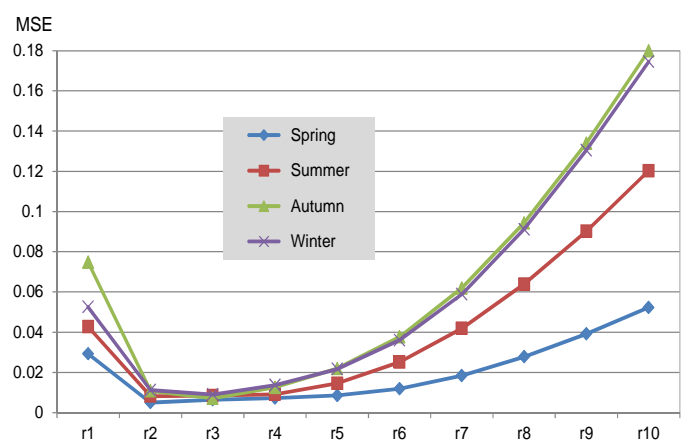

Fig. 6. Seasonal consistency verification (Mar 2009-Feb 2010). MSE: mean squared error.

Thus it is presumed that, as regards holding data in the gateway for a certain period of time, accurate information can be provided to the server if the data of two days are held under the condition of $r=3$.

In order to verify the consistency of the water temperature, $\alpha$ and $\beta$ values are designated as minimum and maximum values based on the difference between the expected value and measured value using the mean values of the past three days. If adopting the bigger one of such differences for 2008 and 2009, the verification of water temperature consistency is as shown in Eq. (5).

$$
s_{n+1}^{*}-0.3983 \leq s_{n+1} \leq s_{n+1}^{*}+0.3425
$$

For the consistency of salinity, by applying the same manner as that of water temperature, we defined $r=2$ and $\alpha$, $\beta$ values are designated as follows,

$$
s_{n+1}^{*}-0.7533 \leq s_{n+1} \leq s_{n+1}^{*}+0.7700
$$

The difference between $\alpha$ and $\beta$ for defining the consistency of water temperature and salinity in Eq. (5) and (6), are somewhat large because the $\alpha$ and $\beta$ values have been induced from the measured data over the course of 12 months. That is the ranges of fault permissions are somewhat large. In order to solve this problem, we separately designate $\alpha$ and $\beta$ values for the data of each season; thus we can reduce the ranges of fault permissions. Following Eq. (7) shows the example of the definition of consistency with water temperature between March 2009 and May 2009, in which the range of water temperature is large.

$$
s_{n+1}^{*}-0.3942 \leq s_{n+1} \leq s_{n+1}^{*}+0.3158
$$

For the integrity of definition 2, the following equations have been designated for the water temperature and salinity from the data of 12 months. The range of water temperature is wider than that of salinity; that is the range of fault permission is large for water temperature. In order to solve this problem, we can reduce the range of fault permission by separately defining the integrity of the water temperature for each season. Eq. (8) and (9) show the lower bound and upper bound for defining the integrity of March 2009 to May 2009.

Water temperature: $8.09 \leq \mathrm{s}_{\mathrm{i}} \leq 18.37$

Salinity: $29.88 \leq \mathrm{s}_{\mathrm{i}} \leq 33.93$

\section{Identification Process of Data Failure}

The process of identifying data failure by using the defined consistency and integrity is as shown in Figs. 7 and 8 .

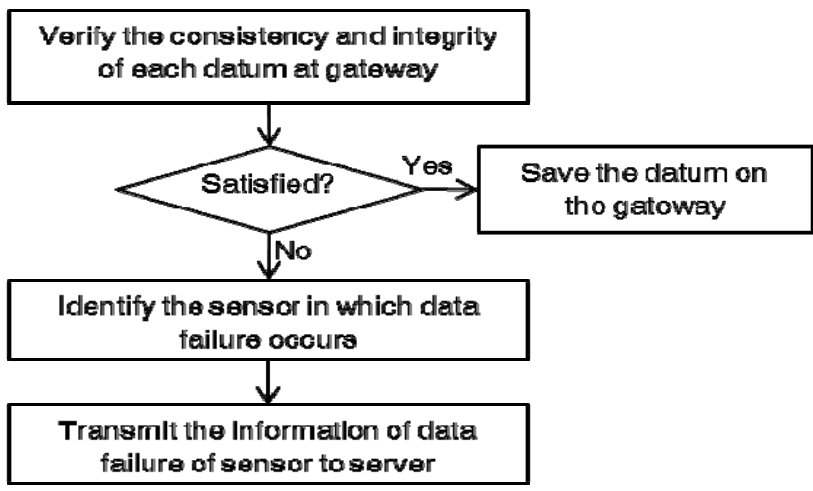

Fig. 7. Data verification at the gateway

Since it is not necessary to define the integrity and consistency for the detecting only the sensors, the integrity and consistency verification is carried out with regard to the measured data from the sensors at the gateway stage in the method shown in Fig. 7. Through such verification, the failure of the sensor can be discovered by violation of the above, and can be identified by notification of such failure to the server.

Next, at the database server, we can identify the gateway that causes the data failure through the process shown in Fig. 8 . 


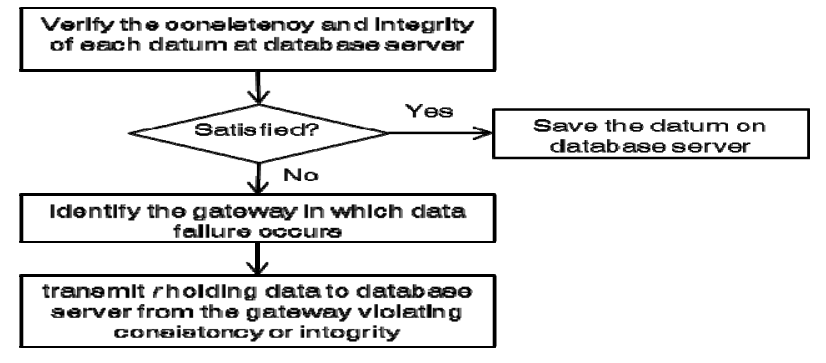

Fig. 8. Data verification at the database server

\section{Recovery Techniques by Failure Type}

Relevant recovery for previously analyzed failure can be performed by identifying the exact type of failure through cause analysis of the failure mentioned above. Table 6 provides a summary of the proposed recovery techniques.

Table 6. Recovery techniques by failure types

\begin{tabular}{|c|c|c|}
\hline $\begin{array}{l}\text { Failure } \\
\text { type }\end{array}$ & $\begin{array}{c}\text { Failure } \\
\text { specification }\end{array}$ & Recovery method \\
\hline \multirow[t]{3}{*}{$\begin{array}{l}\text { System } \\
\text { element } \\
\text { failure }\end{array}$} & Sensor & $\begin{array}{l}\text { Where data is not acquired by gateway from } \\
\text { a sensor for a certain period of time, gateway } \\
\text { notifies sensor failure to server and a physical } \\
\text { correction will be performed }\end{array}$ \\
\hline & Gateway & $\begin{array}{l}\text { Where information is not transmitted from } \\
\text { gateway to server, relevant gateway will be } \\
\text { physically corrected by using timeout }\end{array}$ \\
\hline & $\begin{array}{l}\text { Database } \\
\text { server }\end{array}$ & $\begin{array}{l}\text { Since checking failure at user UI is } \\
\text { impossible, physical correction will be } \\
\text { performed }\end{array}$ \\
\hline \multirow[t]{2}{*}{$\begin{array}{l}\text { Communi- } \\
\text { cation } \\
\text { failure }\end{array}$} & $\begin{array}{l}\text { Water quality } \\
\text { measuring } \\
\text { sensor } \leftrightarrow \\
\text { gateway }\end{array}$ & $\begin{array}{l}\text { Since this can be discovered at the same way } \\
\text { as the failure of water quality measuring } \\
\text { sensor, the same physical correction will be } \\
\text { performed. }\end{array}$ \\
\hline & $\begin{array}{l}\text { Gateway } \leftrightarrow \\
\text { database } \\
\text { server }\end{array}$ & $\begin{array}{l}\text { Since this can be discovered in the same way } \\
\text { as the failure of gateway, the same physical } \\
\text { correction will be performed. }\end{array}$ \\
\hline \multirow[t]{4}{*}{$\begin{array}{l}\text { Data } \\
\text { failure }\end{array}$} & $\begin{array}{l}\text { Data (water } \\
\text { quality } \\
\text { measuring } \\
\text { sensor) }\end{array}$ & $\begin{array}{l}\text { Failure can be confirmed by verification of } \\
\text { consistency and integrity at the gateway and } \\
\text { will be treated as re-transmission of the most } \\
\text { recent } r \text { number of data or as water quality }\end{array}$ \\
\hline & $\begin{array}{l}\text { Data (water } \\
\text { quality } \\
\text { measuring } \\
\text { sensor) } \neq \\
\text { Data } \\
\text { (gateway) }\end{array}$ & measuring sensor failure. \\
\hline & $\begin{array}{l}\text { Data } \\
\text { (gateway) }\end{array}$ & $\begin{array}{l}\text { Failure can be confirmed by verification of } \\
\text { integrity and consistency based on data of } \\
\text { gateway at the server and will be corrected } \\
\text { with non-violating data or treated as the } \\
\text { failure of gateway. }\end{array}$ \\
\hline & $\begin{array}{l}\text { Data } \\
\text { (gateway) } \neq \\
\text { Data } \\
\text { (database } \\
\text { server) }\end{array}$ & $\begin{array}{l}\text { Consistency and integrity of data will be } \\
\text { guaranteed by comparing } r \text { number of } \\
\text { gateway data with } r \text { number of server data } \\
\text { per certain period of time. }\end{array}$ \\
\hline
\end{tabular}

\section{CONCLUSIONS}

It is very important to discover failure in a marine USN system using expensive sensors in a harsh environment such as underwater or in the ocean and to devise recovery techniques as a method for dealing with the failure.

Thus this study analyzed the 'USN-based real-time water quality monitoring service' in Songdo Island of Yeosu built to manage the environment of Gaduri Aqua Farms and performed modeling of the failure of a coastal marine USN environment. Failures were classified into system element failures, communication failures, and data failures, and the methods of discovering the cause of failure and the method of recovering from them were proposed. In particular, to solve errors from the perspective of data, integrity and consistency of data were defined for use in identifying data failure.

Also, this study proposed guidelines to implement for recovery in accordance with the types of failure identified through the analysis of failure causes. In addition, the suggested length of time to hold data in the gateway stage in the case of data failure was determined through experiment.

In the future, studies on handling data quality to secure accuracy and high quality of marine water quality environmental data transmitted from the sensors to the sensor nodes, gateway, AP, and server will be performed.

\section{ACKNOWLEDGMENTS}

This research was financially supported by the Ministry of Education, Science Technology (MEST) and National Research Foundation of Korea (NRF) through the Human Resource Training Project for Regional Innovation.

\section{REFERENCES}

[1] J. Yick, B. Mukherjee, D. Ghosal, "Wireless sensor network survey," Computer Networks, vol.52, no. 12, pp. 2292-2330, 2008.

[2] L. Gavrilovska, S. Krco, V. Milutinovic, I. Stojmenovic, and R. Trobec, Application and multidisciplinary aspects of wireless sensor networks: concepts, integration, and case studies, London: Springer-Verlag, 2011.

[3] D. H. Ryu, H. J. Na, and S. H. Nam, "Implementation of a USNbased disaster prevention system in Korea," International Journal of Computers, vol. 3, no. 1, pp. 11-19, 2009.

[4] Y. M. Kim, "Concept, types and terms of USN technology," Seminar materials on USN Technology and Standard Trend, Seoul, 2006.

[5] National IT Industry Promotion Agency (NIPA), "Report on 2006's USN site testing result," Seoul: NIPA, 2007. 
[6] Korea Hydrographic Oceanographic Administration (KHOA), "Suncheon Bay USN marine cluster and convergence service system," Incheon: KHOA, 2010.

[7] Songdo Island of Yeosu-City [Internet]. Available: http://www.yeosusongdo.com.

[8] Korea Hydrographic and Oceanographic Administration [Internet]. Available: http://www.khoa.go.kr.

[9] E. S. Youk, S. U. Yun, and S. H. Kim, "Development of fault detection algorithm applicable to sensor network system," Journal of Fuzzy Logic and Intelligent Systems, vol. 17, no. 6, pp. 760-765, 2007.

[10] G. Gupta and M. Younis, "Fault-tolerant clustering of wireless sensor networks," Wireless Communications and Networking, vol. 3, pp.1579-1584, 2003.

[11] A. Akbari, A. Dana, A. Khademzadeh, and N. Beikmahdavi, "Fault detection and recovery in wireless sensor network using clustering," International Journal of Wireless \& Mobile Networks, vol. 3, no. 1, pp. 130-138, 2011.

[12] F. Koushanfar, M. Potkonjak, and A. Sangiovanni-Vincentell, "Fault tolerance techniques for wireless ad hoc sensor networks," Proceedings of IEEE Sensors, Orlando, pp. 1491-1496, 2002.
[13] T. Clouqueur, K. K. Saluja, and P. Ramanathan, "Fault tolerance in collaborative sensor networks for target detection," IEEE Transactions on Computers, vol. 53, no. 3, pp. 320-333, 2004.

[14] G. Huang, Y. Zhang, J. He, and J. Cao, "Fault tolerance in data gathering wireless sensor networks," The Computer Journal, vol. 54, no. 6, pp. 976-987, 2011.

[15] P. Jiang, "A new method for node fault detection in wireless sensor networks," Sensors, vol. 9, no. 2, pp. 1282-1294, 2009.

[16] P. Jiang, H. Xia, Z. He, and Z. Wang, "Design of a water environment monitoring system based on wireless sensor networks," Sensors, vol. 9, no. 8, pp. 6411-6434, 2009.

[17] C. Li, G. Tan, J. Wu, Z. Zhang, and L. Xu, "A LEACH-head expected frequency appraisal algorithm for water-environment monitoring networks," International $J$ of Communications, Network and System Sciences, vol. 4, no. 9, pp. 562-567, 2011.

[18] Open Standards and Internet Association, "A study on secure management of sensor network in USN service," Korea Internet \& Security Agency, Seoul, Report No. KISA-WP-2009-0042, 2009.

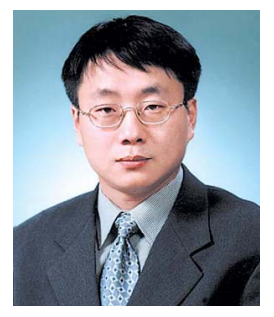

\section{Hee-Taek Ceong}

received the B.S., M.S., and Ph.D. degrees in Computer Science from Chonnam National University, Kwangju, Korea in 1992, 1995, and 1999, respectively. Since 1999, he has been a professor in the Department of Digital Convergence, Chonnam National University, Yeosu, Korea. His research interests include data analysis, RFID/USN systems, and multimedia.

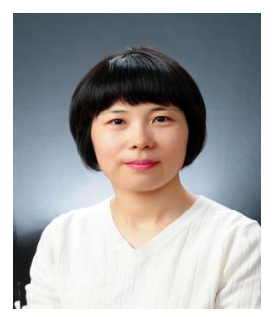

\section{Hae-Jin Kim}

received the B.S. degrees in political science and diplomacy from Chosun University, Kwangju, Korea in 2000. She is currently pursuing the M.S. degree in digital convergence, Chonnam National University, Yeosu, Korea.

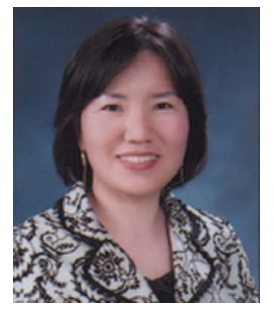

\section{Jeong-Seon Park}

received her BS and MS from the Department of Computer Science, Chungbuk National University, Chungbuk, Korea, in 1992 and 1994, respectively. She also received her PhD from the Department of Computer Science, Korea University, Seoul, Korea in 2005. Since 2005, she has been a professor in the Division of Culture Contents, Chonnam National University, Chonnam, Korea. Her research interests include image processing, pattern recognition, and IT convergence applications. She is a member of IEEE, KIISE, and KING Computing. 